УДК 94(477.8-89Гал):2]:327(470)"1914/1917"

DOI https://doi.org/10.32838/2663-5984/2021/3.10

\title{
Ковбаса В.М.
}

Тернопільський національний педагогічний університет імені Володимира Гнатюка

\section{РЕЛІГІЙНА ПОЛІТИКА РОСІЙСЬКОЇ ОКУПАЦІЙНОЇ ВЛАДИ В ГАЛИЧИНІ ТА БУКОВИНІ (1914-1917 РР.)}

У статті досліджено принщипи формування, організації та подальшої діяльності органів російської окупаційної влади щодо іудейського та протестантського населення Східної Галичини та Північної Буковини під час Першої світової війни. Аналітичні побудови здійснено на основі розгляду архівних матеріалів та історіографії. Хронологічно дослідження охоплює 1914-1917 рр.(від початку війни 28 червня 1914 р. до Лютневої револючії 1917 р.).

Євреї та німиі-протестанти розглядалися як внутрішні вороги, шзо становлять небезпеку для Російської імперії ще перед активним розгортанням військових дій. Перша світова війна спраџювала як каталізатор, внаслідок чого відбулася акумулячія антисемітських та ксенофобських настроїв у суспільстві за сприяння політичної пропаганди окупачійної адміністраиіï.

Російська влада звинувачувала єврейське та німеиьке населення в шпигунстві на користь Австро-Угорщини та Німеччини, а також прагненні дестабілізувати військову, політичну та соиіально-економічну ситуацію в окупованих регіонах. Окупаційна адміністрація намагалася здобути лояльність місиевого населення, здійснюючи репресї та привласнюючи майно німиів та євреїв. Простежено причетність військового керівництва та солдатів російської армії до організачії погромів. Зазначається наявність таких явищ як біженство, взяття заручників та примусове виселення.

Зроблено висновок, щуо політика російської окупачійної адміністрачії в Східній Галичині та Північній Буковині в 1914-1917 рр. продиктована не лише завданням сприяти забезпеченню потреб армії та полегшенню відносин між армією та місиевим населенням, а й була спрямована на інтеграцію і русифікацію иих регіонів, до якої можна віднести мовний, освітній та релігійний складники. Діяльність російської влади мала яскраво виражений антисемітський характер і була спрямована проти місцевого єврейства та німиів-протестантів, а також підданих Росії.

Ключові слова: Перша світова війна, Східна Галичина, Північна Буковина, Росія, АвстроУгорщина, Німеччина, окупачія, антисемітизм, репресії, погроми, євреї, німиі, протестанти.

Постановка проблеми. Розгляд релігійної політики російської окупаційної адміністрації у Східній Галичині та Північній Буковині в 1914-1917 рр. надає можливість комплексного розуміння розгортання подій Першої світової війни у соціополітичному контексті, оскільки між арміями двох військових блоків опинилося цивільне населення, для якого бойові дії стали важким випробуванням. Актуальним проблемним питанням постає вплив подій Першої світової війни на єврейське та протестантське населення Центральної і Східної Європи.

Аналіз останніх досліджень i публікацій. В історіографії окреслено політичний і гуманітарно-інформаційний вектори досліджень щодо проблем біженства, громадських організацій i культури війни, проте проблемне питання цієї статті ще не знайшло належного висвітлення. Більшість наукових екскурсів стосуються саме українського населення Галичини та Буковини. У цьому контексті привертають увагу дослідження С. В. Адамовича [2], І. Г. Патера [24], О. Я. Мазура [19], І. В. Барана [4], В. І. Сергійчука [30], В. І. Любащенка [16; 17], Ю. Є. Решетнікова [27], а також праці І. Г. Лозинської [15], Ф. І. Стеблія [32], I. С. Монолатія [21]. Безпосередньою складовою джерельної бази дослідження стали документи Державного архіву Тернопільської області (ДАТО) [9; 10].

Постановка завдання. Мета статті - розгляд релігійної політики російської окупаційної влади щодо іудейського та протестантського населення Східної Галичини та Північної Буковини під час Першої світової війни. Задля досягнення мети окреслено наступні завдання: розгляд історіографії, вивчення архівних документів, встановлення причинно-наслідкових зв'язків, а саме причетності військового керівництва та солдатів 
російської армії до організації погромів і наслідки таких дій.

Виклад основного матеріалу дослідження. У серпні - вересні 1914 р. в результаті Галицької битви російська армія просунулася на 280-300 км, зайнявши Галичину та Буковину до жовтня 1914 р. Російська влада стала офіційно називати захоплену територію «зайнятою за правом війни» i розпочала формування нових органів управління на окупованих землях. Було ліквідовано всі структури австрійської влади, натомість створено систему російської адміністрації, яку очолював воєнний генерал-губернатор. Головним іiї завданням було сприяння забезпеченню потреб армії та полегшення відносин між армією та місцевим населенням [15].

Напередодні війни відповідно до перепису 1910 р. національний склад населення Галичини був таким: $46 \%$ становили поляки, $42 \%$ - українці, $11 \%$ - євреї та $1 \%$ - німці. У Східній Галичині більшість склали українці (62\%), а також поляки (25\%) та євреї (12\%) [12, с. 654]. Чисельність єврейського населення зростала через високий рівень народжуваності та втечі від погромів із західних губерній Російської імперії [33].

Буковина за національним складом була більш строкатою за Галичину, однак реальне співвідношення визначити важко через значні маніпуляції під час проведення переписів - змінювалися прізвища, інколи навіть назви сіл. У 1910 р. $38,1 \%$ населення Північної Буковини становили українці; молдовани та румуни - 34,2\%; євреї $12,8 \%$; німці - 9\%; поляки, угорці, вірмени та чехи $-5,9 \%$ [18, с. 229].

Якщо політична влада та земля перебували в руках поляків, румунів і німців, то підприємництво та торгівля - в руках євреїв. Станом на 1910 p. 77\% євреїв працювали в сфері торгівлі, промисловості, а також займалися ремеслами. Відповідно до цього за чисельністю вони становили 40-45\% від населення міст і були посередниками між містом та селом [12, с. 654]. Проте більшість євреїв Галичини та Буковини жили в умовах страшенної бідності та розглядалися, як головне втілення цивілізаційної відсталості в імперії, хоча на початку війни єврейські громади Австро-Угорської та Російської імперій активно підтримували патріотичні гасла своїх урядів.

У Росії на шпальтах єврейської преси 3'являлися статті войовничого та патріотичного характеру, а в синагогах проводилися богослужіння про перемогу російській армії. Почали друкуватися єврейські російськомовні журнали
«Евреи на войне» [11] та «Война и евреи» [7], що обстоювали виключно патріотичні позиції. Намагаючись продемонструвати лояльність російських євреїв до влади та піднести бойовий дух, ці видання друкували матеріали про подвиги та героїзм євреїв на фронтах війни.

Незважаючи на політичну лояльність євреїв та враховуючи віросповідання і традиції, їх розглядали як потенційно нелояльних до Російської імперії, тому постійно утискали.

У свою чергу, єврейська еліта імперії Габсбургів підтримувала австро-угорську владу здебільшого тому, що ворогом Австро-Угорщини була «антисемітська Росія», а також через те, що активна проавстрійська позиція у війні обіцяла єврейській громаді повне й остаточне визнання в «дуалістичній» монархії. Війна з Росією сприймалася як боротьба цивілізованої країни з «азійським деспотизмом». На це вказував текст відозви Єврейської національної партії Буковини, поширений восени 1914 р.: «Ми, австрійські євреї, що користуємося під скіпетром великодушного і справедливого цісаря усіма громадянськими політичними правами та свободою, натхненно вирушаємо на війну 3 метою боронити нашу дорогу вітчизну... У цій боротьбі й ми, євреї, боремося за плоди тисячолітньої культурної праці, в якій наші батьки на Заході та Півдні Європи брали активну участь, і ми, євреї, боремося з азійським деспотизмом, поневоленням народів...» [23, с. 114].

Одразу ж після вступу російської армії на територію Галичини та Буковини єврейське населення зазнало значних репресій, хоч об'єктивних причин для цього не було. Начальники повітів у звітах до військового генерал-губернатора окупованих областей Австро-Угорщини графа Г. Бобринського, зазначали, що єврейське населення, хоч i не можна вважати таким, що співчуває та симпатизує Росії, поводиться коректно без жодної ворожості [10]. Проте також наголошували на симпатії до імперії Габсбургів та прихованому ворожому ставленні [10, арк. 35-36]. Втім, це не стало на заваді російській владі, яка продовжувала звинувачувати євреїв у шпигунстві на користь Австрії та спекуляціях продуктами першої необхідності, а саме скуповуванні міді та хліба [2].

Прихід російських військ супроводжувався численними погромами і пограбуваннями, вбивствами та знущанням над цивільним єврейським населенням. Війна спричинила підвищення цін та зниження рівня життя. Оскільки торговцями були переважно євреї, їх було звинувачено у штучному завищенні цін та спекуляціях. 
Зі спогадів С. Ан-ського (псевдонім, справжнє ім'я та прізвище Шлойме Зайнвіл Аронович Раппопорт) [29] відомо, що: «Пограбуванням було піддано всі міста після захоплення їх росіянами. Козаки грабували все (...), але більше всього крамниці, фактично, головним чином постраждали саме євреї» [3]. Сплюндровано, пограбовано та знищено сотні синагог і єврейських молитовних домів. Десятки тисяч галицьких євреїв рятувалися від російських військ втечею в центральні та західні регіони Австро-Угорщини.

Російська армія захопила Львів без бою, а 3 вересня 1914 р. градоначальником щойно захопленого міста призначили колишнього волинського віце-губернатора, полковника С. Шереметьєва, який обіцяв не влаштовувати репресій проти євреїв за умови, якщо вони будуть поводитися «відповідно». На зустрічі з єврейськими представниками Ф. Шляйхером, Я. Діамандом, Г. Рабнером, рабином Л. Брауде та професором Б. Гауснером С. Шереметьєв заявляв, що не створюватиме різниці між християнами та євреями, зберігатиме справедливість і цінуватиме їхні права. Проте від них він вимагав не переховувати солдат - євреїв, видавати владі кожного втікача, не допускати пошкодження телефонного обладнання на своїх дільницях, не збиратися на вулицях і не вступати в діалог із солдатами, не поширювати чуток і фальшивих відомостей. За недотримання цих вимог С. Шереметьєв погрожував покараннями згідно із законами воєнного часу, які були оголошені в синагогах [24, с. 383].

18 вересня 1914 р. очільником Львова замість C. Шереметьєва призначено генерал-майора Ейхе, від середини жовтня його замінив полковник О. Скалон, поліцмейстер у Мінську [25]. 27 вересня в єврейському районі міста вчинено перший масштабний погром, який назвали «кривавою неділею» [13, с. 724].

Ярослав Левицький, український греко-католицький священник, так описував події, свідком яких став: «Важливішою подією 3 перших днів російської інвазії був погром євреїв. Се було в неділю пополудні. Коло третьої години почув я зі сторони ринку сильну стрілянину 3 крісів. Чим далі стрілянина змагалась. Віддавало цілі сальви. Так тривало доброї півгодини. Згодом почулись стріли також з інших сторін Львова. Ми були певні, що у Львові з'явились австрійські патрулі. Моє помешкання виходило вікнами на касарняний город. Виглянувши через вікно, побачив я на вулиці повно солдатів, приготованих до стрілу. 3 вулиці Театинської (тепер вул.
М. Кривоноса - примітка автора) бігли поодинокі уоружені солдати в сторону ринку. Я відчинив вікно, щоби поспитатись солдатів, що сталось. Та лише вихилив голову, як накинувся на мене один солдат з криком: «Зачиняти вікно, бо стріляємо» [22, с. 266].

Внаслідок проведеного слідства російською владою конфісковано три єврейські будинки [25, с. 115] на вулиці Валовій [22, с. 266], захоплено нових заручників та вивезено з міста на заслання окремих представників єврейської громади [25, с. 115]. Насамперед у заручники брали найвпливовіших та найвизначніших людей усіх національностей i станів. Зі Львова утримували в заручниках 37 осіб, серед них - 15 євреїв, зокрема А. Бек - доктор медицини, професор університету; краєві адвокати Я. Діаманд, Я. Райх; Л. Гольдман - власник ресторану. Заручниками 3 Львівської губернії були 523 особи єврейської національності [19].

Сврейські погроми та переслідування відбувались і в інших населених пунктах Галичини та Буковини. Зайнявши містечко Устя Борщівського повіту, російські військові прогнали все єврейське населення, а їхні будинки знищили з фундаментом. Зруйнували навіть підвали в пошуках грошей і коштовностей. Зберігся лише дім кредитної кооперативи «Руський Народний Дім», у котрому розташовувалася офіцерська їдальня, а також греко-католицька парафіяльна забудова - будинок учителя С. Гаймановича та єврея Розенштока, де знаходилася кухня [4]. У Коломиї на євреїв було накладено своєрідну контрибуцію за «неправдиві дані» про свою власність. Переслідування відбувалися в Чернівцях, Станіславі, Самборі та інших містах [25, с. 115].

Рядовий російської армії О. Пірейко, перебуваючи в Галичині, у спогадах наголошував на жорстокому поводженні російських військових із єврейським населенням, яке часто без причин звинувачували у шпигунстві. Наприклад, «полковник Барановський, начальник гарнізону, все зло бачив тільки в євреях. Для нього було цілком достатньо для побиття та ув'язнення, коли російські солдати-мародери приводили до нього типового єврея з пейсами і казали що це - шпигун». У травні полковник Барановський «віддав наказ озброїти 57-му етапну роту палицями i холодною зброєю та відправив громити євреїв у місті» [26, с. 27].

У телеграмі губернатору Галичини від 28 грудня 1914 р. начальник штабу Верховного головнокомандувача, генерал від інфантерії 
М. Янушкевич підкреслював: «репресії дисциплінують єврейське населення, змушуючи його відчувати твердість російської влади... Відповідні заходи викличуть бажане масове виселення євреїв за кордон» [30].

Особливо посилювалися антисемітські настрої після поразок на фронті, а також унаслідок політичної пропаганди. Традиційно євреїв звинувачували у «шпигунстві на користь Австрії і Німеччини» та «революційному підриві дисципліни в армії». Антисемітська агітація посилювалася в пресі, цензурою заборонявся друк повідомлень про героїзм євреїв на фронтах. Щойно ситуація на фронті стабілізувалась - кількість погромів різко зменшилася [26, с. 28].

13 лютого 1915 р. військовий генерал-губернатор граф Г. Бобринський видав спеціальну обов'язкову постанову щодо обмеження руху євреїв на території Галичини та Буковини. У преамбулі вказувалося, що на основі наказу Головнокомандувача армії Південно-Західного фронту, генерала від артилерії М. Іванова [8] у зв'язку 3 посиленням шпигунства 3 боку євреїв необхідно встановити низку заборон та обмежень у пересуванні: заборонити в’їзд до Галичини особам єврейської національності та переїзд із одного повіту до іншого. Винних у порушенні цієї постанови притягнути до накладання штрафу в сумі трьох тисяч рублів або утримання у в'язниці до трьох місяців [1].

В інструкції від 14 лютого 1915 р., розісланій генерал-губернаторством у повіти, лунали заклики до органів влади на місцях: «3 особливою увагою стежити за діяльністю євреїв i за найменших підстав застосовувати проти них репресії..., щоб місцеве християнське населення могло відчути себе звільненим від терору, який поширюють євреї» [2, с. 25]. Згодом міський секретар Кіцманю Мойсей Таненбаум згадував про знущання росіян над євреями: «Дня 15 лютого 1915 о 3-й годині вночі витягнули мене російські жандарми 3 постелі та разом 3 іншими єврейськими закладниками відставили в Галичину. Солдати ескорту били до крові стариків. Бувало й кололи списами, коли громада не йшла скоро. Навіть дітям не жалували нагайок» $[22$, c. 445]. Загалом лише у Кіцманському повіті Буковини за період з 27 листопада 1914 року по 21 листопада 1915 року пограбовано 13 маєтків поміщиків, 3 заводи, спалено кілька сотень хат та господарських будівель, переважно єврейських, розстріляно 13 осіб (серед яких 12 євреїв), депортовано 446 осіб (з них 331 євреї) [6].
Черговим складним питанням, яке постало перед російською адміністрацією у Східній Галичині і Буковині, була проблема єврейського землеволодіння. Секретар фракції націоналістів, депутат IV Державної думи Д. Чіхачов розробив власну програму діяльності адміністрації на окупованих територіях, яка передбачала задля «умиротворення» краю, підняття благоустрою корінного «російського» населення й об'єднання його 3 Російською імперією ліквідувати місцеве єврейське землеволодіння. Користуючись становищем, коли частина євреїв-землевласників втекла 3 австрійською армією і покинула свої володіння, слід «невідкладно конфіскувати якнайбільше єврейських маєтків, а євреїв - орендаторів і управляючих з їхніми сім'ями вислати 3 орендованих і керованих ними маєтків» [5].

Віце-директор дипломатичної канцелярії Ставки верховного головнокомандувача М. Базілі в записці до Великого князя Миколи Миколайовича пропонував розпочати негайну ліквідацію великого єврейського землеволодіння. Оскільки євреї володіли $35 \%$ поміщицької власності, а 3/4 цієї землі фактично знаходилися в їхніх руках унаслідок розвитку «посесорства», всю цю землю необхідно було передати в кредит селянам, щоб у такий спосіб підірвати єврейське засилля [20]. Г. Бобринський, виступаючи 25 січня 1915 р. перед спеціально привезеними до Чернівців селянами, обіцяв наділити їх землею за рахунок маєтків євреїв-утікачів [24, с. 395].

Проте вже в квітні 1915 р. генерал-губернатор Г. Бобринський визнав лояльність єврейського населення. Він зазначав, що галицьким євреям, які користуються в краю повною рівноправністю, важко відмовлятися від деякої внутрішньої ворожості до російської влади, але їхня поведінка в межах генерал-губернаторства не має жодного ворожого характеру. Він також висловив думку, що галицькі євреї згодом стануть інструментом русифікації краю. Це припущення найбільше підтверджувалося у Львові, Чернівцях, Станіславові та інших містах, де єврейські купці, незважаючи на неприязнь до Росії, дуже швидко і ревно почали використовувати російську мову в торговельній cфepi [25, c. 115].

В Міністерстві закордонних справ Російської імперії також розуміли, що основним принципом управління завойованими територіями до закінчення війни повинно бути не «сліпе» переслідування політичних цілей, а створення умов, які б полегшували виконання військових завдань зміцнення і стабілізація тилу. При цьому підкрес- 
лювалося, що лишається коло питань, які вже під час війни вимагають політичної оцінки й рішень на загальнодержавному рівні, а саме єврейське та українське. Зазначалося, що «ніякі послаблення» в боротьбі 3 проявами українофільства неприпустимі. Щодо євреїв запропоновано зміну тактики. Влада відмовилася від примусових заходів, оскільки практика виселення євреїв із прифронтових територій у 1915 році не дала очікуваних результатів. Тому планувалося введення заборони на повернення біженців із австрійських територій i, відповідно, припинення інфільтрацій євреїв до Східної Галичини [5, с. 83-84].

Встановлений у другій половині 1916 року в Галичині та Буковині російський окупаційний режим Воєнного генерал-губернаторства областей Австро-Угорщини, зайнятих за правом війни, був більш розсудливим і поміркованим за попередній режим зразка 1914-1915 років. У його основу покладено пункти про першочергове лобіювання інтересів і задоволення потреб діючої армії та уникання будь-яких дій, що могли б розпалити політичні та будь-які інші конфлікти серед населення.

Перша світова війна завдала значних втрат i протестантам. Російська влада сприймала протестантське населення «П’ятою колоною», незважаючи на їхню політичну байдужість.

Перше поселення протестантів у Галичині засновано в Заліщиках (Тернопільщина) у 1750 р. вихідцями із Пруссії і Саксонії для роботи на суконній фабриці [36]. Згодом 3'являються міські лютеранські громади у Львові, Замості, Ярославі, узаконені Патентом колонізації від 12 жовтня 1774 р. [36, с. 32]. Станом на середину XIX століття в Галичині існувало 186 колоній [32], заснованих вихідцями з Пруссії, Саксонії, Баварії, Голландії, Фландрії, німцями з Польщі та Чехіï [21].

Громади лютеран і кальвіністів підпорядковувалися одній із регіональних структур Свангелістської Церкви аугсбурзького і гельвецького віровизнання - Галицько-Буковинській суперінтендантурі (єпископату) з осередком у Львові (1804-1870 рр.), Гельсендорфі (Загірному на Львівщині) (1886-1896 рр.) і Бєльсько-Бялій (1871-1885 і 1897-1918 рр.). Напередодні та в часи Першої світової війни спільноту очолював австрійський релігійний діяч i теолог Герман Георг Фріче, пастор у Вінер-Нойштадті (Нижня Австрія) і Бєльсько-Бялій [16]. У 1913 році лютеранська частина нараховувала 29 парафій, 50 церковних філій і 16 місійних станцій із загальною кількістю 52540 прочан. Кальвіністи, у свою чергу, мали 4 парафії, 8 філій, 1 станцію і 4679 вірян [35].

Окрім громад лютеранів і кальвіністів, до 1914 року на теренах Галичини зароджується баптизм - значною мірою під впливом проповідників із Угорщини, Польщі, Румунії і Волині, де вже в середині XIX ст. створено перші громади. Головним чинником баптистської євангелізації Галичини був Німецький баптистський союз, заснований у 1849 році та очолюваний пастором Йоганом Герхардом Онкеном. Своїм пріоритетним завданням союз декларував поширення баптизму в Центральній та Східній Європі [16, с. 263]. Початок його поширення пов'язаний iз діяльністю німецьких та польських баптистів. Ще у 80-х pp. XIX ст. шорник Микола Войтюк зібрав першу молитовну групу баптистів у Коломиї, а на початку XX ст. було сформовано колонію, заселену німцями-баптистами у Вальддорфі Городоцького повіту на Львівщині [16, с. 263]. Згодом баптистські громади існували в багатьох галицьких містах, серед яких - Львів, РаваРуська, Сколе, Жовква, Перемишль, Добромиль. Під час Першої світової війни колоністи розпорошуються по всій Галичині, осідаючи у Вишинцях, Міхаликах, Майдані, Юленівці, Забір'і, Гійчому, Вільоку, Камінці, Салашах [17].

Окрім представників православних служителів культу, на російському боці у війні брали безпосередню участь і протестантські віряни та їхні керівники. Громади надавали матеріальну й моральну допомогу російській армії. Разом з євангельськими християнами вони заснували фонд «Милосердний самарянин», який збирав кошти для організації лазаретів та догляду за пораненими, розповсюджував духовну літературу на фронтах. Баптисти працювали санітарами та військовими будівельниками, деякі 3 них воювали. Незважаючи на це, протестанти зазнавали систематичних арештів, декого примусово висилали до Росії, Південного Кавказу, Сибіру [17, с. 298].

Ситуація погіршувалася тим, що взаємовідносини протестантських вірян і Російської імперії ще в кінці XIX століття були досить непростими. Джерелом напруги була, головним чином, держава через їі православно-монархічну природу й невизначеність релігійного законодавства [27].

Діячі Православної Церкви, скориставшись переважанням у суспільстві шовіністичних настроїв, спричинених військовим станом, розглядали баптистів, адвентистів, євангельських християн як німецьких агентів та зрадників. 
Під час дезінформування населення та звинувачення баптистів в антидержавній діяльності чималу роль відіграло сільське духовенство, яке, конкуруючи із поширенням релігійного вчення баптистів і усвідомлюючи свою відповідальність за парафію, прагнуло використати цей момент задля провокування репресій щодо протестантів; це потенційно зменшило б ступінь їхнього релігійного впливу на населення [14]. Внаслідок цього відбулося масове закриття громад у прифронтовій смузі, яке супроводжувалося конфіскацією молитовних будинків і засланням їхніх очільників. Зауважимо, що навіть участь у відкритті лазаретів для поранених пояснювалася бажанням протестантів вести антиправославну агітацію серед постраждалих. Невдовзі владою висунуто вимогу не допускати баптистів або євангельських християн до лазаретів, навіть якщо вони були відкриті самими прочанами [27, с. 198].

Російська окупаційна влада вважала галицьких протестантів та, зрештою, й німців 3 інших територій Австро-Угорської та Російської імперій етнічними, тому підозрювала їх у потенційному шпигунстві та диверсіях.

Незважаючи на звернення керівництва Галицько-Буковинської суперінтендантури до російської військової адміністрації і навіть до Верховного головнокомандувача царя Миколи II, вже 3 кінця 1914 р. розпочалася депортація місцевих протестантів у Росію (переважно до Сибіру). Спочатку виселенню підлягали всі чоловіки 18-70 років, згодом - їхні родини з дітьми, на збори яких відводилося три доби, потім - лише одна. За спротив передбачались арешт і конфіскація майна [34].

Окрім цього, окупаційна адміністрація видала наказ про заборону православним і католицьким солдатам відвідувати протестантські збори. В 1915 році після успішної для Німеччини та Австро-Угорщини Горлицької операції російська влада розпочала відкриту боротьбу з протестантами [28].

15 вересня 1915 року російські козаки увірвалися до колонії Багінсберг (Коломия - примітка автора), спалили молитовні та будинки мешканців (із 110 вціліло лише 17), а також культурно-освітній осередок «Німецький дім». Попри це суперінтендантурі вдалося зберегти свої найбільші міські громади, зокрема у Львові на початку 1921 р. залишилося 2670 лютеран [37].

За діяльністю протестантів встановлено ретельний нагляд. Наказано піддавати суворим покаранням за межами військового розташування тих, кого буде викрито в антиурядовій діяльності або пропаганді шкідливої віри [28, с. 7]. Особливо наголошувалася необхідність покарання протестантів саме за межами фронту, що було викликано небажанням військового керівництва афішувати та надавати розголосу справам, пов'язаним із поширенням антивоєнних поглядів [9]. Адміністрація не хотіла давати привід для уникнення військової служби солдатам православного віросповідання. Це пояснювалося «м'якими» покараннями за відмову брати зброю до рук та фактами заслання у тил і прифронтові зони [9, арк. 2]. Після звичайних дисциплінарних покарань у своїх частинах, протестантів найчастіше спрямовували на обозну та санітарну службу. Лише невелика частина утримувалася в арештантських батальйонах і в'язницях [9, арк. 3].

Переслідування німців Галичини тривало до останніх днів російської окупації тільки через те, що вони були німцями, а Росія воювала проти Німеччини. У великих містах арештовували інтелігенцію, у провінції - селян-німців. Із одного Городоцького повіту Львівської губернії за підозрою в шпигунстві у травні 1915 р. вивезли 68 родин німецьких колоністів [19].

У 1915 році начальник Волинського жандармського управління наказав звернути особливу увагу та вжити відповідних заходів задля припинення здійснення баптистами пропаганди серед військових [28], що стало однією із причин введення заборони молитовних зібрань у 1917 р. До зборів не допускалися офіцери, військові лікарі, чиновники, а також усі, хто був задіяний у системі оборони, навіть якщо вони були членами протестантських громад [9, арк. 1].

Наприклад, на початку 1917 року начальник 21-ї армійської запасної бригади, частини якої розташовувалися в Тернополі, Микулинцях і Підволочиську, звернувся до Тернопільського Губернатора 3 проханням повідомити, чи проводяться в районі дислокації частин його бригади збори протестантів. Якщо стане відомо, що такі збори проводяться таємно, то слід видати розпорядження для поліції, яка повинна проводити арешти та складати іменні списки присутніх. Згодом ці списки із вказаними частинами надсилалися безпосередньо начальнику бригади [9, арк. 1].

Дискримінація та утиски євреїв і протестантів припинилися лише після перемоги Лютневої революції 1917 р. 3 приходом до влади Тимчасового уряду у Росії. Починаючи з березня 1917 р., почали звільняти частину засуджених, до числа яких потрапляли й ув'язнені за релігійні переконання [31]. 
Висновки. Підбиваючи підсумки, слід зазначити, що євреї та німці-протестанти розглядалися в якості внутрішніх ворогів Російської імперії. Такий стан речей спостерігався ще перед активним розгортанням військових дій під час Першої світової війни: ці групи населення зазнавали релігійних та економічних утисків з боку окупаційної влади. Надалі насилля набуло системного характеру.

Російська влада звинувачувала єврейське та німецьке населення в шпигунстві на користь Австро-Угорщини й Німеччини та прагненні дес- табілізувати військову, політичну та соціальноекономічну ситуацію в окупованих регіонах. Через здійснення репресій і привласнення майна євреїв та німців адміністрація намагалася здобути лояльність місцевого населення.

Таким чином, діяльність російської окупаційної адміністрації у Галичині та Буковині в 1914-1917 рр. мала виражений антисемітський характер і була спрямована проти місцевого єврейства та німців-протестантів, а також підданих Росії.

\section{Список літератури:}

1. Авербах Е. И. Законодательные акты, вызванные войною 1914-1916 гг. : законы, манифесты, рескрипты, указы, положения Совета Министров, военного и адмиралтейств советов : распоряжения и постановления министров и др. : Изд. неофиц. : Т. 2-4. [Сост.] Е. И. Авербах Пг., 1915-1916. 3 т. Перед загл. авт. : О. И. Авербах. Т. 2 : [Акты, обнародованные с января по сентябрь 1915 г.]. 1915. XLVIII, 846 с.

2. Адамович С. В. Сврейське питання в політиці російської окупаційної адміністрації в Галичині та на Буковині (1914 - 1917 рр.). Вісник Прикарпатського університету. Історія. 2005. Вип. IX. С. 23-27.

3. Ан-ский С. А. Разрушение Галиции. Архив еврейской истории / [ред. совет : О. В. Будницкий (гл. ред.) [и др.]]. Т. 3. Москва, 2006. С. 9-30.

4. Баран I.В. Вплив бойових дій на становище міст і сіл Східної Галичини на початку Першої світової війни. Вісник національного університету «Львівська політехніка»: «Держава та армія». 2009. № 652. C. $46-55$.

5. Бахтурина А. Ю. Политика Российской Империи в Восточной Галиции в годы Первой мировой войны : [монография]; предисл. В. В. Шелохаева. Москва : [АИРО-ХХ], 2000. 263 с. : ил. (Первая монография).

6. Буковина: історичний нарис. Відп. ред. Ботушанський В.М. Чернівці : Зелена Буковина, 1998. 416 с.

7. Война и евреи. - СПб. : тип. М. Стасюлевича, 1914. VI. 288 с.

8. Волковинський В.М. ІВАНОВ Микола Іудович [Електронний ресурс]. Енциклопедія історії України: Т. 3: Е-Й / Редкол.: В. А. Смолій (голова) та ін. НАН України. Інститут історії України. К.: В-во «Наукова думка», 2005. 672 с.: іл. - URL: http://www.history.org.ua/?termin=Ivanov_M (останній перегляд: 07.04.2021)

9. Державний архів Тернопільської області, м. Тернопіль. Ф. 322. Оп. 1. Спр. 244. Арк. 1-3.

10. Державний архів Тернопільської області, м. Тернопіль. Ф. 322. Оп. 1. Спр. 2. Арк. 13, 53, 68-69, 86, 96, 153.

11. Евреи на войне: двухнедельный иллюстрированный журнал. Москва : 1915. №4.

12. Економічна історія України : іст.-екон. дослідж. : в 2 т. / [Т. А. Балабушевич, В. Д. Баран, В. К. Баран та ін. ; відп. ред. В. А. Смолій] ; НАН України, Ін-т історії України. - Київ : Ніка-Центр, 2011. Т. 1 . 2011. 694 с. : іл., табл.

13. Кандель Ф. Евреи России : времена и события. История евреев Российской империи. Науч. ред. М. Кипнис. Москва : Мосты культуры, Гешарим, 2014. 800 с.

14. Клибанов А. История религиозного сектантства в России (60-е годы ХIX в. - 1917 г.). Москва : Наука, 1965. 348 с.

15. Лозинська I. Г. Організація російського цивільного управління у Галичині (серпень-вересень 1914 року). Східноєвропейський історичний вісник. 2017. Вип. 2. С. 21-30. - URL: http://nbuv.gov.ua/ UJRN/eehb 201725

16. Любащенко В., Петрів Н. :Юридичний статус протестантських громад Галичині (1781-1921), «Історія релігій в Україні», книга I, упор.: О. Киричук, М. Омельчук, І. Орлевич, Львів : 2015. С. 262-271.

17. Любащенко В. І. Історія протестантизму в Україні : курс лекцій. Київ : Поліс, 1996. 350 с.

18. Магочій Павло-Роберт. Ілюстрована історія України = Ukraine: An Illustrated History : пер. 3 англ. / Павло-Роберт Магочій; пер. С. Біленький. Київ: Критика, 2012. 446, [1] с., [24] арк. іл. : іл.

19. Мазур О. Я. Міграція населення Східної Галичини на початку Першої світової війни: заручники, біженці, вигнанці, евакуйовані. Вісник Національного університету «Львівська політехніка». Держава та армія. 2013. № 752. С. 50-61. URL: http://nbuv.gov.ua/UJRN/VNULPDA_2013_752_12

20. Международные отношения в эпоху империализма : документы из архивов царского и Временного правительств 1878-1917 гг. : Серия 3 : 1914-1917. М. ; Л. : Гос. соц.-экон. изд-во, 1931-1938. [Т. 6 : Ч. $1: 5$ 
августа 1914 г. - 13 января 1915 г.] / подгот. к печати А. Л. Попов, при участии Б. Я. Галиной и В. В. Альтмана. 1935. XIX, с. 335.

21. Монолатій I. Австро-німецька колонізація Галичини кінця XVIII - другої половини XIX століть: напрямки, тенденції, підсумки. URL: http://kalusz.io.ua/s206088/nimecka_kolonizaciya_prikarpattya

22. Московська окупація Галичини 1914 - 1917 рр. в свідченнях сучасників. (Галицький архів). Львів : Апріорі, 2018. 528 с. : іл.

23. Нариси з історії та культури євреїв України / упоряд. та ред. Л. Фінберг, В. Любченко. Вид. 3-тє. Київ : Дух і літера, 2009. 437 с. : іл.

24. Патер І.Г. Статус окупованих територій Галичини і Буковини в 1914-1917 рр. Історія державної служби в Україні : у 5 т. Т. 1. К., 2009. С. 379-409.

25. Петрович І. [Крип'якевич І.]. Галичина під час російської окупації: Серпень 1914 - червень 1915. Львів, 1915. $116 \mathrm{c}$

26. Пирейко А. М. В тылу и на фронте империалистической войны : воспоминания рядового. [предисл. В. Залежского] ; Отд. ЦК ВКП(б) по изучению истории Окт. революции и ВКП(б). Львів : Прибой, 1926. $62 \mathrm{c}$.

27. Решетников Ю. Обзор истории евангельскобаптистского братства в Украине. Ю. Решетников, С. Санников. Одесса : Богомыслие, 2000. 246 с. «История Евангельского движения в Евразии: Материалы и документы (1.1)». Одесса, 2004.

28. Савчук Т. «Дарма брат брата вбиває»: протестанти в армії Російської імперії (1914-1917рр.). Емінак. 2015. № 1-2. C. 5-10. URL: http://nbuv.gov.ua/UJRN/eminak_2015_1-2_3.

29. Сергєєва I. А. Архівна спадщина Семена Ан-ського у фондах Національної бібліотеки України імені В. І. Вернадського. НАН України, Національна бібліотека України імені В. І. Вернадського, Центр досліджень історії і культури східноєвропейського єврейства. Київ .: ДУХ І ЛІТЕРА, 2006. 544 с. URL: http://irbis-nbuv.gov.ua/everlib/item/er-0001845

30. Сергійчук В. Погроми в Україні: 1914-1920. Від штучних стереотипів до гіркої правди, приховуваної в радянських архівах. Київ : В-во О.Теліги, 1998. 544 с.

31. Сітарчук Р.А. Адвентисти сьомого дня в українських землях у складі Російської імперії (друга половина XIX століття - 1917 рік): монографія. Полтава : Скайтек, 2008. 324 с.

32. Стеблій Ф. 3 історії взаємин українців і німецьких поселенців у Галичині у середині XIX ст. Німецькі колонії Галичини: Історія-Архітектура-Культура. Матеріали Міжнар. наук. семінару. Львів, 1996. С. 125.

33. "Canadian Slavonic Papers»: Ivan L. Rudnytsky. Mychailo Drahomaniv and the Problem of UkrainianJewish Relations. Canadian Slavonic Papers. 1969. № 2. P. 182-198.

34. Gastpary W. Kościół Ewangelicko-Augsburski podczas pierszej wojny światowej. Księga jubileuszowa z okazji 70-lecia urodzin ks. prof. dr. Jana Szerudy. Warszawa. 1959. S. 22.

35. Johannes-Mathesius-Gesellschaft - Evangelische Sudetendeutsche e.V.: Die Evangelische Kirche A. u. H. B. in Österreich im Jahr. 1913. URL: https://archiv.mathesius.org/089n.shtml

36. Lepucki H. Działalność kolonizacyjna Marii Teresy i Józefa II w Galicji 1772-1790: z 9 tablicami i mapą. Lwów. 1938. S. 28.

37. Pierwszy powszechny spis Rzeczpospolitej Polskiej z dnia 30 IX 1921 roku. Mieszkania, ludność, stosunki zawodowe. Warszawa, 1927. S. 54.

\section{Kovbasa V.M. RELIGIOUS POLICY OFTHE RUSSIAN OCCUPATIONAUTHORITIES IN GALICIA AND BUKOVINA (1914-1917)}

The article is devoted to the principles of formation, organization and activities of the Russian authorities against Jewish and Protestant inhabitants of Eastern Galicia and Northern Bukovina during the First World War. The work based on the analysis of archival materials and historiography. The study covers 1914-1917 (from the beginning of the First World War on June 28, 1914 to the February Revolution in 1917).

Even before the active deployment of hostilities, Jews and Protestant Germans were determined as internal enemies that posed a danger to the Russian Empire. The First World War was a catalyst of an accumulation of anti-semitic and xenophobic sentiments in society, which was facilitated by the political propaganda of the occupation administration.

The Russian occupation authorities accused the Jewish and German locals of spying for Austria-Hungary and Germany to destabilizate military, political, and socioeconomic situation in the occupied regions. The administration tried to gain loyalty of locals through repression and misappropriation of Jewish and German property. The involvement of the military leadership and soldiers of the Russian army in repressions and massacres are traced. 
In conclusion, the policy of the Russian occupation administration in Eastern Galicia and Northern Bukovina in 1914-1917 aimed at integration and russification of the region, include linguistic, educational and religious components. Despite it authorities justified the violence with the military necessity and facilitation of relations between the army and the local population. The vectors of activities of the Russian administration had a pronounced anti-semitic character and were directed against local Jews and Protestant Germans, as well as Russian nationals.

Key words: The First World War, Eastern Galicia, Northern Bukovina, Russia, Austria-Hungary, Germany, occupation, anti-semitism, repression, massacre, Jews, Germans, Protestants. 